\title{
Changes in mGlu5 Receptor-Dependent Synaptic Plasticity and Coupling to Homer Proteins in the Hippocampus of Ube3A Hemizygous Mice Modeling Angelman Syndrome
}

\author{
Marco Pignatelli, ${ }^{1,2 \star}$ Sonia Piccinin, ${ }^{1,2 \star}$ Gemma Molinaro, ${ }^{3}$ Luisa Di Menna, ${ }^{3}$ Barbara Riozzi, ${ }^{3}$ Milena Cannella, ${ }^{3}$ \\ Marta Motolese, ${ }^{3}$ Gisella Vetere, ${ }^{4,5}$ Maria Vincenza Catania, ${ }^{6,7}$ Giuseppe Battaglia, ${ }^{3}$ Ferdinando Nicoletti, ${ }^{1,3}$ \\ Robert Nisticò, ${ }^{1,4}$ and Valeria Bruno ${ }^{1,3}$ \\ ${ }^{1}$ Department of Physiology and Pharmacology, Sapienza University of Rome, 00185 Rome, Italy, ${ }^{2}$ Pharmacology of Synaptic Plasticity Unit, European Brain \\ Research Institute, 00143 Rome, Italy, ${ }^{3}$ Istituto di Ricovero e Cura a Carattere Scientifico (IRCCS) Neuromed, 86077 Pozzilli, Italy, ${ }^{4}$ IRCCS Fondazione Santa \\ Lucia, 00143 Rome, Italy, ${ }^{5}$ Institute of Cell Biology and Neurobiology, National Research Council, 00143 Rome, Italy, ${ }^{6}$ Institute of Neurological Sciences, \\ National Research Council, 95126 Catania, Italy, and ${ }^{7}$ IRCCS Oasi Maria SS, 94018 Troina, Italy
}

\begin{abstract}
Angelman syndrome (AS) is caused by the loss of Ube3A, an ubiquitin ligase that commits specific proteins to proteasomal degradation. How this defect causes autism and other pathological phenotypes associated with AS is unknown. Long-term depression (LTD) of excitatory synaptic transmission mediated by type 5 metabotropic glutamate (mGlu5) receptors was enhanced in hippocampal slices of Ube $3 \mathrm{~A}^{\mathrm{m}-/ \mathrm{p}^{+}}$mice, which model AS. No changes were found in NMDA-dependent LTD induced by low-frequency stimulation. mGlu5 receptor-dependent LTD in AS mice was sensitive to the protein synthesis inhibitor anisomycin, and relied on the same signaling pathways as in wild-type mice, e.g., the mitogen-activated protein kinase (MAPK) pathway, the phosphatidylinositol-3-kinase (PI3K)/ mammalian target of rapamycine pathway, and protein tyrosine phosphatase. Neither the stimulation of MAPK and PI3K nor the increase in Arc (activity-regulated cytoskeleton-associated protein) levels in response to mGlu5 receptor activation were abnormal in hippocampal slices from AS mice compared with wild-type mice. mGlu5 receptor expression and mGlu1/5 receptor-mediated polyphosphoinositide hydrolysis were also unchanged in the hippocampus of AS mice. In contrast, AS mice showed a reduced expression of the short Homer protein isoform Homer $1 \mathrm{a}$, and an increased coupling of mGlu 5 receptors to Homer $1 \mathrm{~b} / \mathrm{c}$ proteins in the hippocampus. These findings support the link between Homer proteins and monogenic autism, and lay the groundwork for the use of mGlu5 receptor antagonists in AS.
\end{abstract}

Key words: Angelman syndrome; hippocampus; Homer proteins; LTD; metabotropic glutamate receptors

\section{Introduction}

Long-term depression (LTD) of excitatory synaptic transmission mediated by type 5 metabotropic glutamate (mGlu5) receptors is amplified in the hippocampus of Fmrl knock-out mice modeling fragile X syndrome (FXS; Huber et al., 2002; Bear et al., 2004), a genetic disorder associated with autism in $\sim 30-35 \%$ of affected children (Kelleher and Bear, 2008). Pathological behavioral phenotypes of Fmrl knock-out mice are corrected by germline manipulations that reduce the expression of mGlu5 receptors (Dölen et al., 2007) or by treatments with negative allosteric

Received May 2, 2013; revised Feb. 11, 2014; accepted Feb. 18, 2014.

Author contributions: M.P., S.P., G.M., F.N., R.N., and V.B. designed research; M.P., S.P., G.M., L.D.M., B.R., M.C., M.M., and G.V. performed research; G.M., M.V.C., and G.B. analyzed data; F.N., R.N., and V.B. wrote the paper.

We thank Prof. P. Worley, Department of Neuroscience, Johns Hopkins University School of Medicine, Baltimore, MD, for kindly providing Arc antibody.

${ }^{*} M$.P. and S.P. contributed equally to this work.

The authors declare no competing financial interests.

Correspondence should be addressed to Valeria Bruno, MD, PhD, Department of Physiology and Pharmacology, Piazzale Aldo Moro 5, 00185 Rome, Italy. E-mail: valeria.bruno@uniroma1.it.

DOI:10.1523/JNEUROSCI.1846-13.2014

Copyright $\odot 2014$ the authors $\quad 0270-6474 / 14 / 344558-09 \$ 15.00 / 0$ modulators (NAMs) of mGlu5 receptors (Bhakar et al., 2012; Michalon et al., 2012), suggesting that exaggerated mGlu5 receptor activity contributes to the pathophysiology of FXS. Moving from these findings, clinical studies are underway to test the effectiveness of mGlu5 receptor NAMs in the treatment of FXS (for review, see Krueger and Bear, 2011; Hagerman et al., 2012).

Aberrant protein synthesis lies at the core of synaptic modifications associated with FXS (Feng et al., 1995), and mGlu5 receptor-dependent LTD in the hippocampus relies on dendritic protein synthesis (Huber et al., 2000; but see also Moult et al., 2008; Waung and Huber, 2009). Because an aberrant protein synthesis is a common motif of autism spectrum disorders (Kelleher and Bear, 2008), there is increasing interest in examining mGlu5 receptor activity in other models of monogenic autism. Auerbach et al. (2011) found that mice carrying heterozygous loss-of-function mutations of the tuberous sclerosis complex-2 (Tsc2) showed a reduced mGlu5 receptor-dependent LTD in the hippocampus. Some of the phenotypes of Tsc2 ${ }^{+/-}$ mice were corrected by cross-breeding with Fmrl knock-out mice or by treatment with a positive allosteric modulator of mGlu5 receptors. Thus, deviations in either direction in mGlu5 


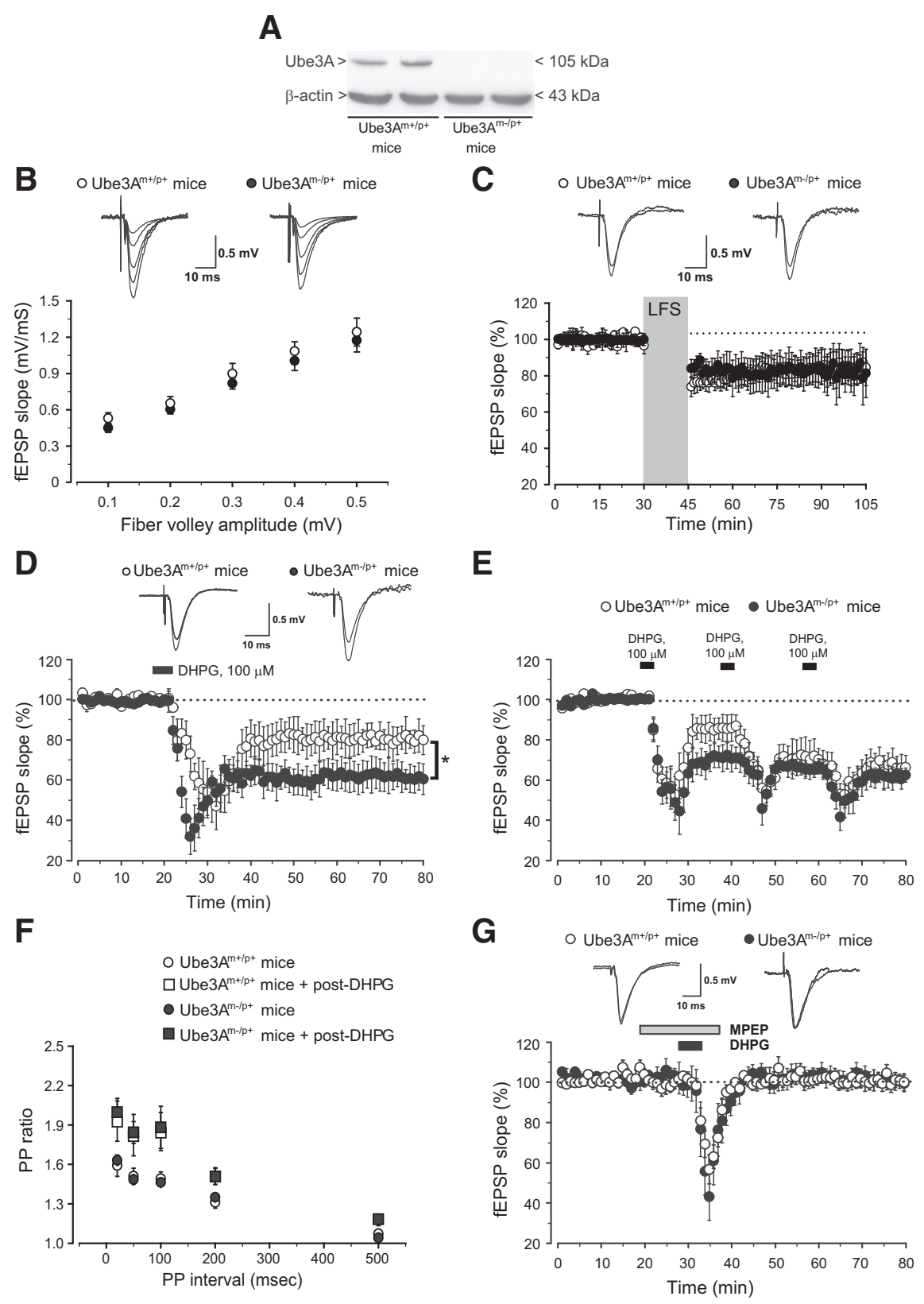

Figure 1. Enhanced mGlu5 receptor-dependent LTD in Ube $3 A^{\mathrm{m}-/ \mathrm{p}+}$ mice. $\boldsymbol{A}$, Immunoblot analysis of Ube $3 \mathrm{~A}$ in hippocampal slices from Ube $3 A^{\mathrm{m}+/ \mathrm{p}+}$ (wild-type) mice and Ube $3 \mathrm{~A}^{\mathrm{m}-/ \mathrm{p}+}$ mice. $\boldsymbol{B}$, Input- output relation of fEPSPs as a function of presynaptic fiber volley size at the $S$ chaffer collateral/CA1 pyramidal cell synapses. Each plot represents $7-8$ separate recordings for each strain. Superimposed representative fEPSPs evoked in response to increasing stimulus intensity are shown. C, LTD induced by low-frequency stimulation (LFS; $1 \mathrm{~Hz}, 15 \mathrm{~min}$ ) of Schaffer collaterals. The fEPSP slope (mean $\pm \mathrm{SEM}$ ) is plotted as percentage of the pre-LFS baseline. Insets show fEPSPs from a representative experiment during a baseline interval and 60 min after LTD. D, LTD induced by bath application of DHPG $(100 \mu \mathrm{m}, 5 \mathrm{~min})$. Values are means \pm SEM of data obtained from slices of $9-12$ mice for each strain. ${ }^{*} p<0.05$ (2-tailed unpaired Student's $t$ test) versus values obtained in slices from wild-type mice. $\boldsymbol{E}$, Depression of fEPSP induced by two consecutive applications of DHPG in slices from wild-type and Ube $3 \mathrm{~A}^{\mathrm{m}-/ \mathrm{p}+}$ mice. Values are means \pm SEM of data obtained from eight mice for each strain. $F$, PPF induced by pairs of stimulation delivered at several interstimulus intervals $(20$, $50,100,200,500 \mathrm{~ms}$ ) at baseline and $60 \mathrm{~min}$ after DHPG application. Data (means \pm SEM) are expressed as the ratio between the second and the first response. $G$, Synaptic depression induced by DHPG $(100 \mu \mathrm{m}, 5 \mathrm{~min})$ in the presence of MPEP (10 $\mu \mathrm{M})$ in slices from wild-type and Ube3A mice. Values are means \pm SEM of data obtained from 7-8 mice for each strain.

receptor-mediated protein synthesis and synaptic plasticity can lead to shared pathological phenotypes (Auerbach et al., 2011).

Here, we examined mGlu5 receptor-dependent synaptic plasticity in a mouse model of Angelman syndrome (AS), a disorder characterized by developmental delay, epilepsy, hyperactivity, and autistic features (Steffenburg et al., 1996; Williams, 2005). AS is caused by mutations or deletions of the maternally inherited Ube3A gene, because the paternal allele of Ube $3 \mathrm{~A}$ is epigenetically silenced in neurons (Kishino et al., 1997). A mouse model of AS has been generated by knocking out $3 \mathrm{~kb}$ of the sequence orthologous to exon 2 of the human Ube3A gene (Jiang et al., 1998). Ube3A is an E3 ubiquitin ligase, which provides substrate specificity to the ubiquitin proteasome system (UPS). The UPS plays a critical role in the regulation of synaptic plasticity (Ehlers, 2003; Dong et al., 2008), and Ube3A knock-out mice display impaired hippocampal longterm potentiation (Jiang et al., 1998, Weeber et al., 2003) and visual cortex plasticity (Yashiro et al., 2009; Sato and Stryker, 2010). Here, we report that AS mice show a selective amplification of mGlu5 receptormediated LTD in the hippocampus and alterations in mGlu5 receptor coupling to Homer proteins.

\section{Materials and Methods}

Drugs. (RS)-3,5-dihydroxyphenylglycine (DHPG), 2-methyl-6-(phenylethynyl)-pyridine (MPEP), (E)-2-methyl-6-stryrylpyridine(-)-2-oxa-4-aminocyclo[3.1.0] hexane-4, 6-dicarboxylic acid (LY367385), U0126, D-2-amino-5-phosphonopentanoic acid (DAP5), UBE1-41, and anysomicin were obtained from Tocris Cookson. Phenylarsine oxide (PAO) and rapamycin were obtained from Sigma-Aldrich.

Animals. Heterozygous Ube3A mice were purchased from The Jackson Laboratory (Jackson code: 129-Ube3atm1Alb/J) and maintained in a C57BL/6 background. The genotyping was carried by PCR analysis using the following primers: 5'-GCTCAAGGTTGTATGCCTTGGTGCT-3' (oIMR1965); 5'-AGTTCTCAA GGTAAGCTGAGCTTGC-3' (oIMR1966); and $5^{\prime}$-TGCATCGCATTGTCTGAGTAGGTGTC-3' (oIMR1967; The Jackson Laboratory).

Mice were kept under environmentally controlled conditions (ambient temperature, $22^{\circ} \mathrm{C}$; humidity, $40 \%$ ) on a $12 \mathrm{~h} \mathrm{light/dark} \mathrm{cycle}$ with food and water ad libitum. All experiments were performed on mice of either sex. Experiments were performed following the Guidelines for Animal Care and Use of the National Institutes of Health. All efforts were made to minimize animal suffering and to reduce the number of animals used.

Electrophysiology. Hippocampal slices were prepared from 4-week-old to 5-week-old Ube3A maternal deficient mice (Ube $3 \mathrm{~A}^{\mathrm{m}-/ \mathrm{p}+}$ "AS" mice) and their wild-type (Ube $3 \mathrm{~A}^{\mathrm{m}+/ \mathrm{p}+}$ ) littermates, as previously described (Nisticò et al., 2013). Brains were rapidly dissected out and parasagittal slices $(400 \mu \mathrm{m})$ were prepared and incubated in artificial CSF (ACSF) containing the following (in $\mathrm{mM}$ ): $124 \mathrm{NaCl}, 3.0 \mathrm{KCl}, 1.0 \mathrm{MgCl}_{2}, 2.0 \mathrm{CaCl}_{2}, 1.25 \mathrm{NaH}_{2} \mathrm{PO}_{4}, 26 \mathrm{NaHCO}_{3}, 10$ glucose, saturated with $95 \% \mathrm{O}_{2}, 5 \% \mathrm{CO}_{2}, \mathrm{pH} 7.4$. The CA3 region was not removed from the slices. Slices were allowed to recover for $2-4 \mathrm{~h}$ and then placed on a nylon mesh, completely submerged in a small chamber $(0.8 \mathrm{ml})$, and superfused with oxygenated $\operatorname{ACSF}\left(30-31^{\circ} \mathrm{C}\right)$ at a constant 

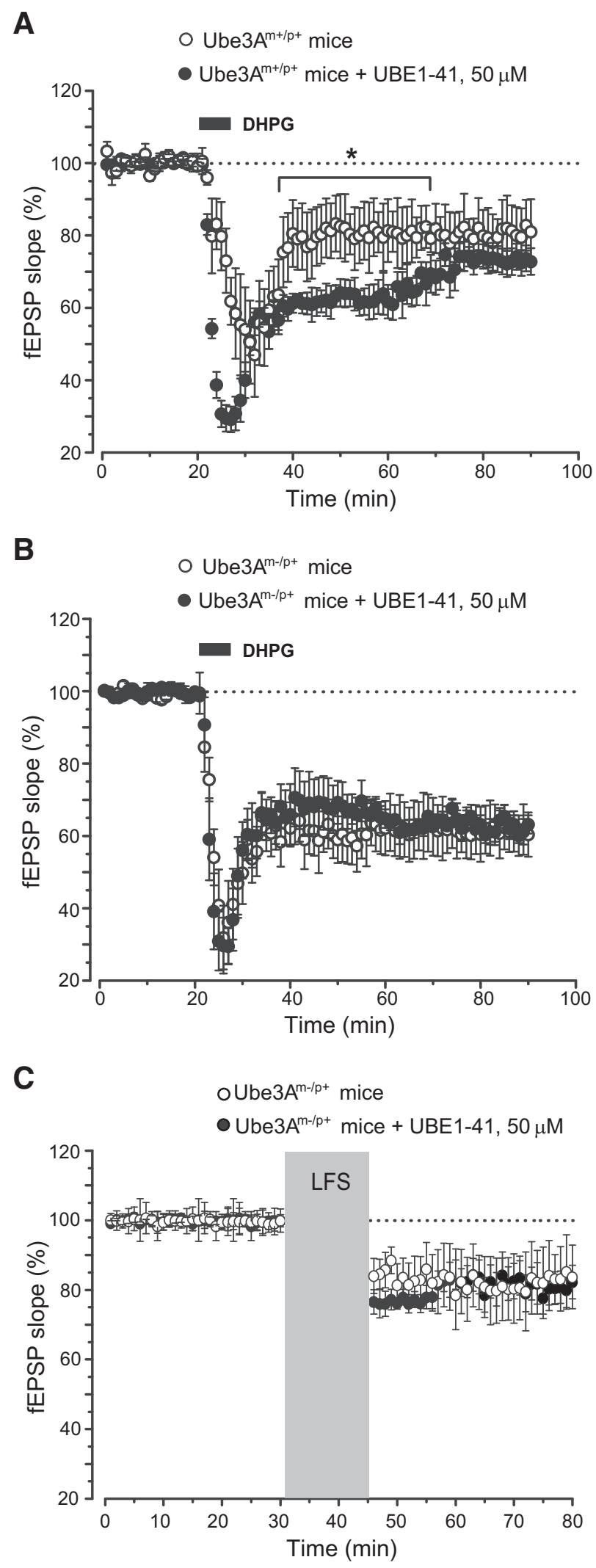

Figure 2. Pharmacological inhibition of proteasomal degradation did not affect synaptic plasticity in AS mice. Slices were preincubated with proteasome inhibitor UBE1-41 for 60 min before recording. $A$, Amplification of DHPG-induced LTD by UBE1-41 in hippocampal slices from wild-type mice. Values are means \pm SEM of data obtained from four mice per group. ${ }^{*} p<0.05$ (2-tailed unpaired Student's $t$ test). $\boldsymbol{B}$, C, The lack of effect of UBE1-41 on DHPG-induced ( $\boldsymbol{B}$ ) or low-frequency stimulation (LFS)-induced (C) LTD in slices from AS mice. Values are means \pm SEM of data obtained from four mice per group. flow rate of $2.5-3.0 \mathrm{ml} / \mathrm{min}$. The slope of the field EPSPs (fEPSPs) was recorded from the apical dendrite layer of the CA1 pyramidal cells by means of saline-filled glass electrodes of $\sim 2-4 \mathrm{M} \Omega$ resistance. Stimulating monopolar electrodes were placed in Schaffer collateral/commissural afferents, and stimulation amplitude was adjusted so as to produce onehalf of the maximal response. Signals were filtered at $3 \mathrm{kHz}$ and digitized at $10 \mathrm{kHz}$. After the stabilization of the fEPSP, LTD was induced by low-frequency stimulation ( $1 \mathrm{~Hz}$ for $15 \mathrm{~min}$ ) or following DHPG application $(100 \mu \mathrm{M}, 5 \mathrm{~min})$. In some experiments DHPG was applied in the presence of the NMDA receptor antagonist D-AP5 $(50 \mu \mathrm{M})$, the proteasome inhibitor UBE1-41 (50 $\mu \mathrm{M})$, the protein tyrosine phosphatase inhibitor PAO $(15 \mu \mathrm{M})$, the mammalian target of rapamycine (mTOR) inhibitor rapamycin $(20 \mu \mathrm{M})$, the extracellular regulated kinase $1 / 2$ (ERK1/2) kinase inhibitor UO126 $(20 \mu \mathrm{M})$, or the protein synthesis inhibitor anisomycin $(20 \mu \mathrm{M})$. D-AP5 was applied $20 \mathrm{~min}$ before DHPG and maintained during the recording session; UBE1-41 (50 $\mu \mathrm{M}$, from a mother solution of $50 \mathrm{~mm}$ in dimethyl sulfoxide) was applied to the slices during the recovery time for $60 \mathrm{~min}$ before placement in the recording chamber (Citri et al., 2009). All the other drugs were applied as indicated (see figures).

Immunoblotting. Slices prepared as described for electrophysiological studies were allowed to recover for $\geq 3 \mathrm{~h}$. Slices were then incubated with DHPG $(100 \mu \mathrm{M})$ for $5 \mathrm{~min}$ and then snap frozen in liquid nitrogen. Samples were homogenized at $4^{\circ} \mathrm{C}$ in a lysis buffer composed of Tris- $\mathrm{HCl}$ 10 mm, pH 7.4; NaCl, 150 mm; EDTA, 5 mm; Igepal 1\%; protease (Santa Cruz Biotechnology) and phosphatase (Sigma-Aldrich) inhibitor mixture. Five microliters of tissue extracts were used for protein determination. Proteins $(30 \mu \mathrm{g})$ were resuspended in SDS-bromophenol blue reducing buffer with $40 \mathrm{~mm}$ DTT and used for protein analysis. Immunoblotting was performed with the following primary antibodies: Ube3A (Bethyl Laboratories), mGlu5 receptor (Millipore Biotechnology), p-ERK1/2 (Thr202/Tyr204; Santa Cruz Biotechnology), ERK (Cell Signaling Technology), p-Akt (Ser473; Cell Signaling Technology), Akt (Cell Signaling Technology), and Arc (activity-regulated cytoskeletonassociated protein; kindly provided by Prof. P. Worley, Department of Neuroscience, Johns Hopkins University School of Medicine, Baltimore, $\mathrm{MD})$. After incubation in primary antibody overnight at $4^{\circ} \mathrm{C}$, immunoblots were incubated with HRP-conjugated secondary antibodies (Calbiochem) and developed by ECL (Hybond ECL, GE Healthcare Europe).

Measurement of polyphosphoinositide hydrolysis in hippocampal slices. Group I mGlu receptor-stimulated polyphosphoinositide (PI) hydrolysis was also measured in hippocampal slices obtained from postnatal day (P) 21-P30 Ube $3 \mathrm{~A}^{\mathrm{m}-/ \mathrm{p}^{+}}$mice and their wild-type littermates as described previously (Nicoletti et al., 1986). Briefly, hippocampi were sliced $(350 \times 350 \mu \mathrm{m})$ using a Mcllwain tissue chopper. Forty microliters of gravity-packed slices were then incubated for $60 \mathrm{~min}$ in $250 \mu \mathrm{l}$ of buffer containing $1 \mu \mathrm{Ci}$ of myo- $\left[{ }^{3} \mathrm{H}\right]$ inositol. Slices were incubated with $\mathrm{LiCl}$ (10 $\mathrm{mm}$ for $10 \mathrm{~min}$ ) followed by DHPG $(100 \mu \mathrm{M})$. One hour later, the incubation was stopped by the addition of $900 \mu \mathrm{l}$ of methanol/chloroform (2:1). After further addition of $300 \mu \mathrm{l}$ of chloroform and $600 \mu \mathrm{l}$ of water, samples were centrifuged at low speed to facilitate phase separation, and the upper aqueous phase was loaded into Dowex 1-X-8 columns for the separation and quantification of $\left[{ }^{3} \mathrm{H}\right]$ Inositolmonophosphate (InsP).

Gene expression analysis by real-time PCR. Total RNA was isolated from hippocampi using TRIzol reagent (Invitrogen) according to the manufacturer's protocol and retrotranscribed into cDNA by using SuperScript III Reverse Transcriptase (Invitrogen). Real-time PCR was performed on the StepOnePlus (Applied Biosystems). PCR was performed by using Power SYBR Green PCR Master Mix Kit (Applied Biosystems) according to the manufacturer's instructions. Thermal cycler conditions were as follows: $10 \mathrm{~min}$ at $95^{\circ} \mathrm{C}, 40$ cycles of denaturation $\left(45 \mathrm{~s}\right.$ at $\left.95^{\circ} \mathrm{C}\right)$, and combined annealing/extension $\left(1 \mathrm{~min}\right.$ at $\left.60^{\circ} \mathrm{C}\right)$. Sequences of primers used were as follows: Homer 1a: forward $5^{\prime}$-TCTTCAGTC TCCTTTGACACCA-3' and reverse $5^{\prime}$-CATGATTGCTGAATTGAATGTG-3'; pan-Homer 1: forward 5' -TGGACTGGGATTCTCCTCTG-3' and reverse $5^{\prime}$-TGTGTCACATCGGGTGTTCT-3'; mGlu 5 receptor: forward 5'-ACGAAGACCAACCGTATTGC-3' and reverse 5'-AGACTT CTCGGATGCTTGGA-3'; cyclophilin A: forward 5' -TCCAAAGACA 
A

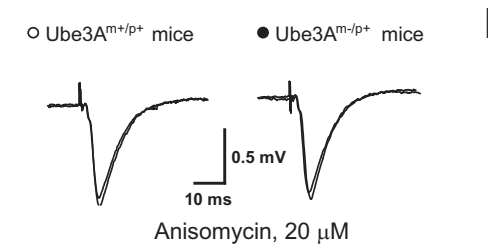

B
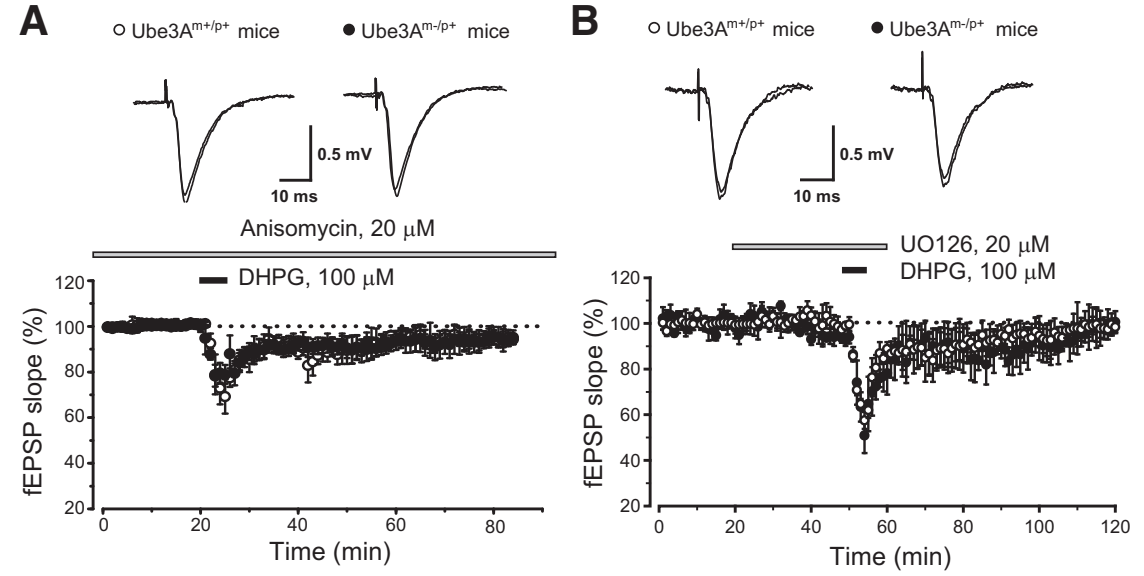

C
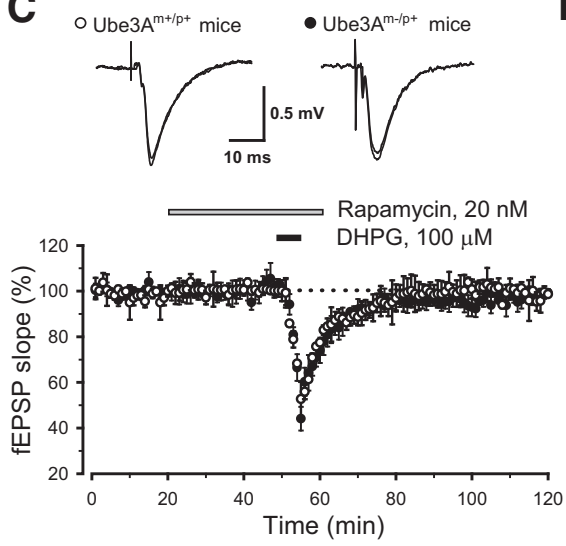

D
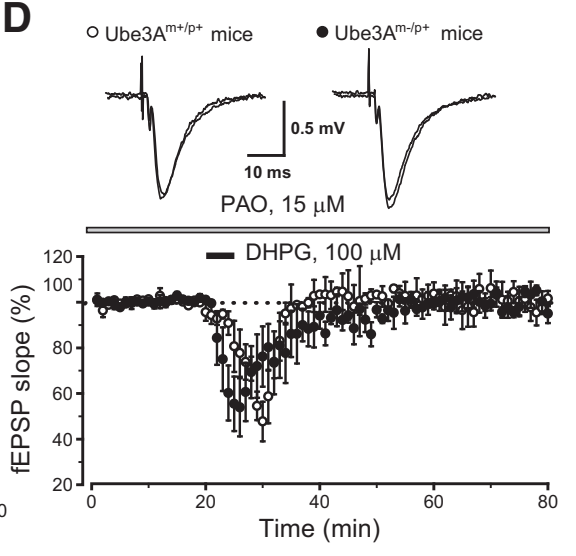

$\mathbf{E}$

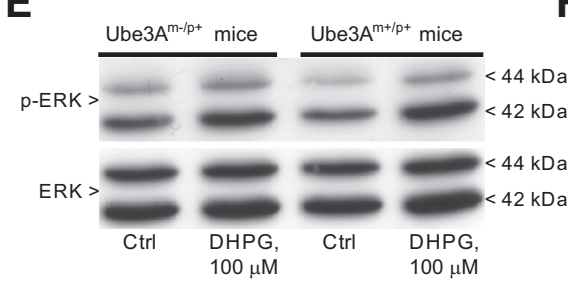

$\mathbf{F}$
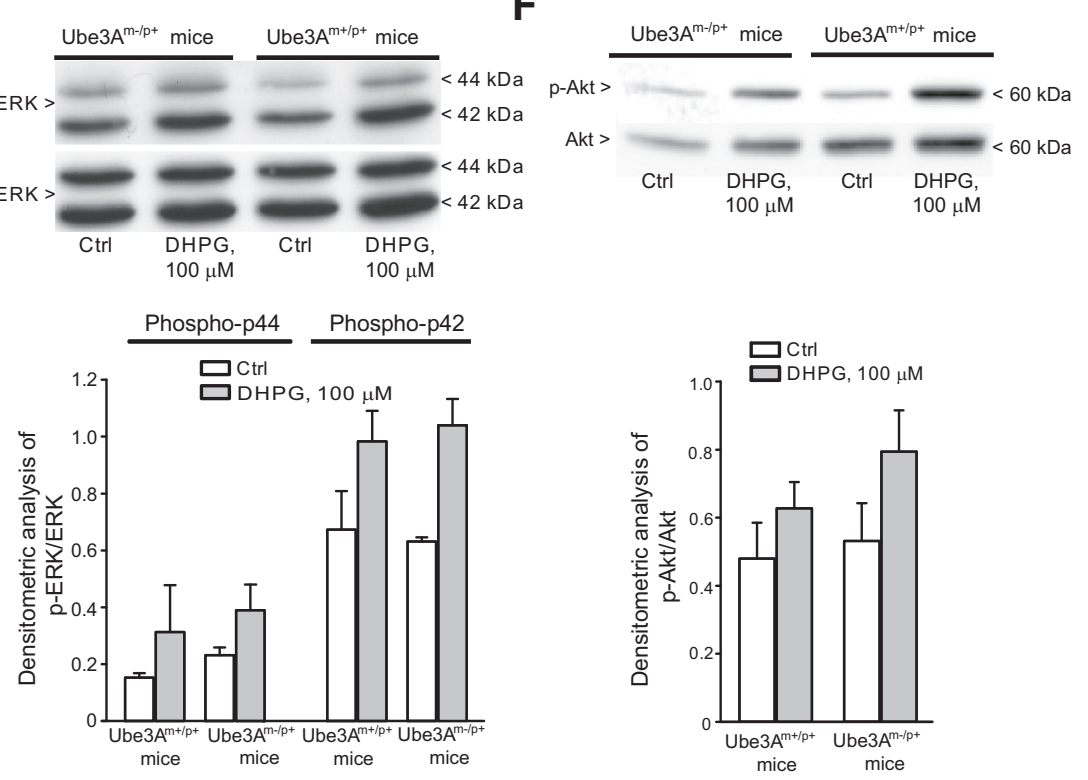

Figure 3. Examination of the intracellular signaling pathways mediating $m G$ lu 5 receptor-dependent $L T D$ in hippocampal slices from wild-type and Ube $3 A^{\mathrm{m}-/ \mathrm{p}+}$ mice. $A-D$, Depression of fEPSP induced by DHPG in the presence of anisomycin $(\boldsymbol{A}), \mathrm{U} 0126(\boldsymbol{B})$, rapamycin $(\boldsymbol{C})$, and $\mathrm{PAO}(\boldsymbol{D})$ in slices from wild-type and Ube $3 \mathrm{~A}^{\mathrm{m}-/ \mathrm{p}+}$ mice. Values are means \pm SEM of data obtained from 4-5 mice for each strain. $\boldsymbol{E}, \boldsymbol{F}$, DHPG-stimulated MAPK $(\boldsymbol{E})$ and PI3K $(\boldsymbol{F})$ pathways in slices from the two genotypes. Values are means \pm SEM from slices obtained from 3-4 individual mice. Two-way ANOVA analysis of $p$-ERK and $p$-Akt data showed a drug effect $\left(F_{(3,28)}=0.355\right.$ and $F_{(3,12)}=0.396$, respectively $)$ but not genotype effect or drug-genotype interaction.

GCAGAAAACTTTCG-3' and reverse 5'-TCTTCTTGCTGGTCTTGC CATTCC-3'.

Concentrations of mRNA were calculated from serially diluted standard curves simultaneously amplified with the samples and normalized versus cyclophilin A mRNA levels.
Coimmunoprecipitation. Hippocampi were homogenized at $4^{\circ} \mathrm{C}$ in a lysis buffer (as above) and $1 \mathrm{mg}$ of total proteins were resuspended in a coimmunoprecipitation buffer $(50 \mathrm{~mm}$ Tris, pH 7.4, 120 mм NaCl, 0.5\% Nonidet P-40, 1 mM EDTA, 1 mM EGTA). Proteins were tumbled overnight at $4^{\circ} \mathrm{C}$ with $5 \mu \mathrm{g}$ of antibody anti-Homer $1 \mathrm{~b} / \mathrm{c}$ or anti-pan-Homer (Santa Cruz Biotechnology). Protein A agarose bead slurry (GE Healthcare) was added for $2 \mathrm{~h}$, and the beads were then washed with coimmunoprecipitation buffer. Western blotting was performed with antibodies against Homer $1 \mathrm{~b} / \mathrm{c}$, pan-Homer, and mGlu5 receptor (Millipore Biotechnology). Protein extracts from the cerebral cortex of normal and mGlu5 receptor knock-out mice (stored in our laboratory) were used as positive and negative controls, respectively.

Statistical analysis. Electrophysiological data were normalized to the averaged value of the initial slope of the fEPSP obtained during the $20 \mathrm{~min}$ period before the application of the conditioning stimulus or DHPG. Data are expressed as the means \pm SEM. Significant differences between groups were determined using two-tailed unpaired Student's $t$ test performed on a $10 \mathrm{~min}$ average taken $50 \mathrm{~min}$ after DHPG application. Statistical significance was set at $p<0.05$. All experiments and the analysis of data were performed in a blind manner. For all statistical comparisons, the $n$ used was the number of animals rather than number of slices. For biochemical experiments, statistical analysis was performed using two-way ANOVA plus Fisher's PLSD test or the Student's $t$ test.

\section{Results}

Enhancement of mGlu5 receptordependent LTD in the hippocampus of AS mice

We measured basal synaptic transmission and activity-dependent synaptic plasticity at the Schaffer collateral-CA1 synapses in hippocampal slices prepared from Ube3A maternal deficient mice (Ube $3 \mathrm{~A}^{\mathrm{m}-/ \mathrm{p}+}$ AS mice) and wild-type (Ube $3 \mathrm{~A}^{\mathrm{m}+/ \mathrm{p}+}$ ) littermates. No Ube3A was detected in hippocampal slices of AS mice, as expected (Fig. $1 A)$. AS mice did not show alterations in basal synaptic transmission (Fig. $1 B ; p>$ 0.05; Jiang et al., 1998), and in LTD induced by low-frequency stimulation, which is known to be dependent on NMDA receptor activation (for review, see Manabe, 1997). Stimulation at $1 \mathrm{~Hz}$ for $15 \mathrm{~min}$ induced a similar depression of synaptic transmission in slices from wild-type and AS mice (wildtype: $85 \pm 9 \%, n=7$; AS: $82 \pm 11 \%, n=8$, $p>0.05$; Fig. $1 C$ ). In contrast, LTD induced by bath application of DHPG $(100 \mu \mathrm{M}, 5$ min) was amplified in AS mice (wild-type: $81 \pm 8 \%, n=9$; AS: $61 \pm 6 \%, n=12, p<0.05$; Fig. $1 D)$. The amplification was unaltered in the presence of the NMDA receptor antagonist, D-AP5 (50 $\mu \mathrm{M} ; 60 \pm 7 \%, n=4)$, excluding any role for endogenous NMDA receptor activation in the DHPG/LTD pheno- 
type of AS mice. As expected (Huber et al., 2001), two consecutive applications of DHPG produced maximal depression of fEPSPs in slices from wild-type mice. In contrast, only one application of DHPG was sufficient to achieve saturated levels of LTD in slices from AS mice, such that maximal depression did not differ between the two genotypes (wild-type: $67 \pm 6 \%, n=8$; AS: $62 \pm 5 \%, n=8, p>0.05$; Fig. $1 E)$. Pairedpulse facilitation (PPF), a presynaptic form of short-term synaptic plasticity (Zucker, 1989), did not differ between wild-type and AS mice at multiple interpulse intervals (Fig. $1 F ; p>0.05)$. The increase in PPF induced by DHPG was also similar between the two genotypes, indicating no changes in the presynaptic component of group I mGlu-receptor-dependent LTD in AS mice (Fig. $1 F ; p>0.05$ ).

We performed pharmacological studies to dissect the relative contribution of mGlu1 and mGlu5 receptors in DHPGinduced LTD in the two genotypes. The mGlu5 receptor NAM MPEP $(10 \mu \mathrm{M})$ abolished DHPG-induced LTD in both genotypes (wild-type: $98 \pm 3 \%, n=7$; AS: $98 \pm 4 \%, n=8$; Fig. $1 G$; for data with MPEP in normal mice, see Faas et al., 2002; Hou and Klann, 2004; Volk et al., 2006). In contrast, DHPGinduced LTD was unaffected by the mGlul receptor antagonist LY367385 (3 $\mu \mathrm{M})$ in both wild-type and AS mice (data not shown). Thus, activation of mGlu5 receptors mediated DHPG-induced LTD in both genotypes.

Knowing that both DHPG-induced and NMDA receptordependent LTD are affected by ubiquitination inhibitors (Citri et al., 2009), we induced LTD in slices preincubated for $1 \mathrm{~h}$ with the proteasome inhibitor UBE1-41 $(50 \mu \mathrm{M})$. DHPG-induced LTD was amplified by UBE1-41 in slices from wild-type mice during the first 40 min after DHPG (Fig. 2A). In contrast, UBE1-41 did not affect DHPG-induced LTD in slices from AS mice (Fig. 2B), indicating that the action of the proteasome inhibitor was occluded by the lack of Ube3A. We also examined NMDA receptordependent LTD induced by low-frequency stimulation in AS mice, finding no effect of UBE1-41 application (Fig. 2C).

\section{Examination of the signaling pathways mediating the enhanced mGlu5 receptor-dependent LTD in AS mice} We first examined whether DHPG-induced LTD in wild-type and AS mice under our experimental conditions was sensitive to the protein synthesis inhibitor anysomicin $(20 \mu \mathrm{M})$. This treatment abolished DHPG-induced LTD in both genotypes. (Fig. 3A).

Multiple intracellular signaling pathways, including the mitogenactivated protein kinase (MAPK) pathway, the phosphatidylinositol3-kinase (PI3K)/Akt/mTOR pathway, and tyrosine phosphatase (PTP)-dependent pathways, are involved in mGlu5-receptordependent LTD in the hippocampus (for review, see Gladding et al., 2009; Collingridge et al., 2010; Lüscher and Huber, 2010). We examined the involvement of these three pathways by inducing mGlu5 receptor-dependent LTD in the presence of the PTP inhibitor PAO $(15 \mu \mathrm{M})$, the ERK1/2 kinase inhibitor U0126 (20 $\mu \mathrm{M})$, or the mTOR inhibitor rapamycin $(20 \mathrm{nM})$. Treatment of hippocampal slices with each of these inhibitors had no effect on basal synaptic transmission but fully blocked DHPG-induced LTD in both wild-type and AS mice (Fig. $3 B-D ; p>0.05$ ). In addition, all these treatments did not reverse changes in PPF induced by DHPG (data not shown). These data suggest that mGlu5 receptor-dependent LTD has the same molecular requirements in the two genotypes. In addition, DHPG-induced phosphorylation of ERK1/2 and Akt in hippocampal slices did not differ significantly between wild-type and AS mice (Fig. 3 E, F). It was still possible that Ube3A-target proteins that are regulated by the MAPK or PI3K/Akt/mTOR pathways in response to mGlu5 receptor activation could be altered in AS mice. We measured the expression of Arc, the product of an early inducible gene that has been implicated in mechanisms of mGlu5 receptor-dependent LTD (Park et al., 2008; Waung et al., 2008). Basal Arc protein levels did not change in hippocampal slices from AS mice (Fig. 4; Greer et al., 2010). A 5 min exposure of hippocampal slices to DHPG $(100 \mu \mathrm{M})$ increased Arc protein levels to the same extent in wild-type and AS mice (Fig. 4).

\section{Enhanced coupling of mGlu5 receptors with the long isoforms of Homer proteins in the hippocampus of AS mice} We next examined the possibility that the enhancement of mGlu5 receptor-dependent LTD could rely on mechanisms that lie upstream in the signal propagation. mGlu5 receptor mRNA and protein levels were not altered in the hippocampus of AS mice (Fig. 5A, $B$ ). We extended the analysis to agonist-stimulated PI hydrolysis, which represents the canonical signal transduction pathway activated by mGlu5 receptors (for review, see Nicoletti et al., 2011). DHPG enhanced [ ${ }^{3} \mathrm{H}$ ] InsP formation to the same extent in hippocampal slices prepared from wild-type and AS mice (Fig. 5C). Interaction between mGlu5 receptors and Homer proteins (Tu et al., 1998; Xiao et al., 1998) has been implicated in LTD induction (Ronesi and Huber, 2008; Takayasu et al., 2010; Ronesi et al., 2012). Interestingly, mRNA and protein levels of the short, activity-induced Homer 1a isoform were reduced in the hippocampus of AS mice, whereas levels of the long, constitutive Homer $1 \mathrm{~b} / \mathrm{c}$ isoforms were unchanged (Fig. $5 D, E$ ). We also measured mGlu5 receptor protein levels in hippocampal protein immunoprecipitated with either pan-Homer or Homer $1 \mathrm{~b} / \mathrm{c}$ antibodies. mGlu5 receptor levels were significantly increased in pan-Homer immunoprecipitates from AS mice, compared with wild-type mice (Fig. 5F). A significant increase in mGlu5 receptor levels was also found in Homer 1b/c immunoprecipitates from AS mice (Fig. 5G).

\section{Discussion}

Drug treatment of AS remains an unmet clinical need, and pharmacological options to control symptoms of the disease have been only partially effective. Ube3A has been implicated 
A

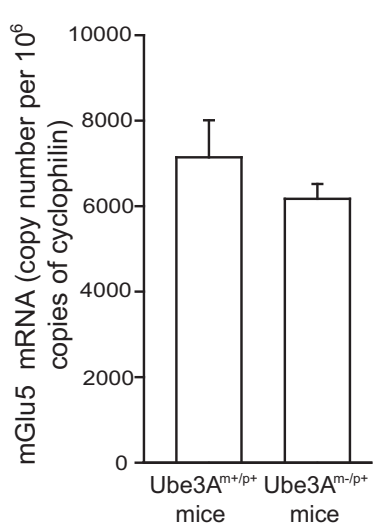

D

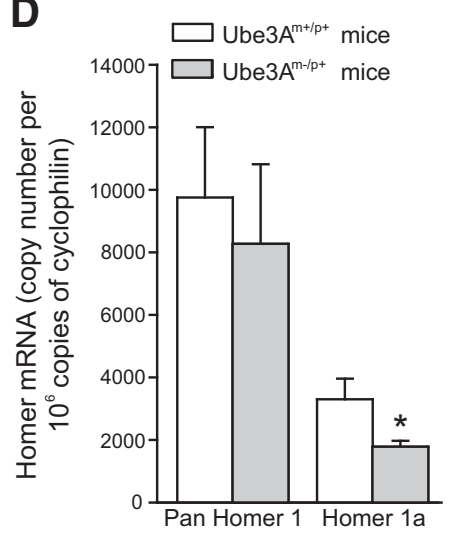

$\mathbf{F}$
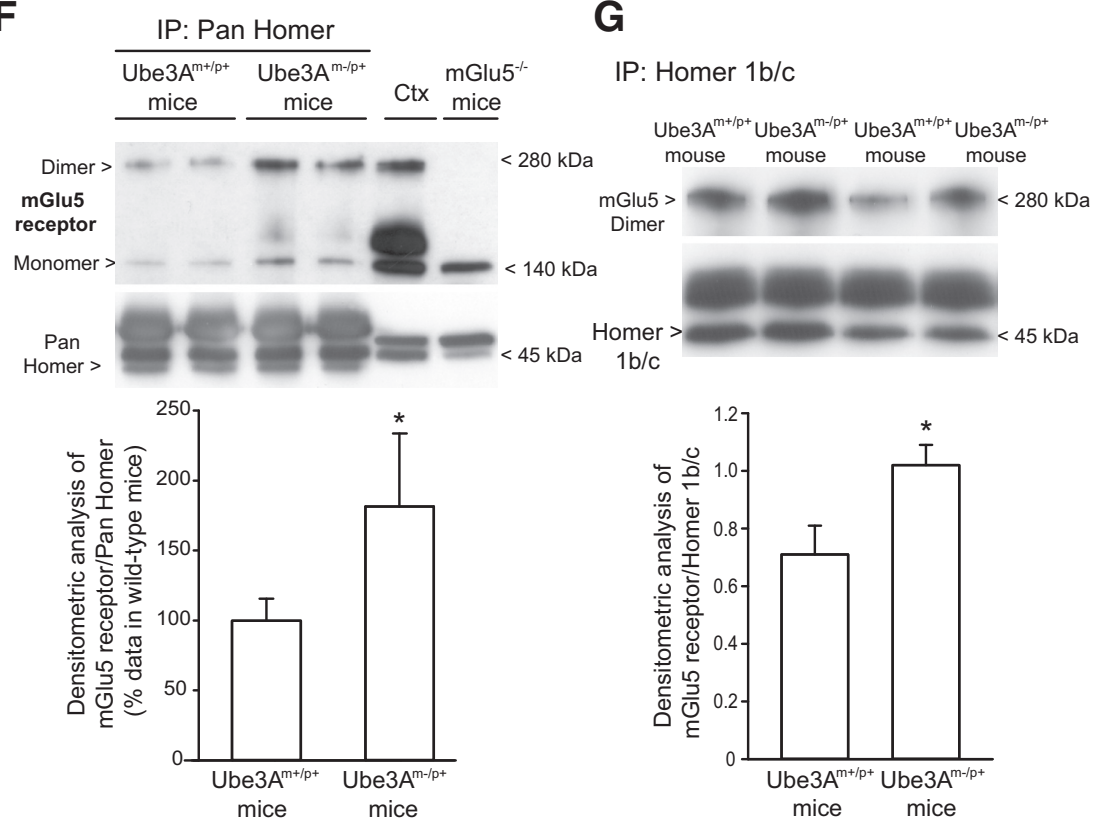

B

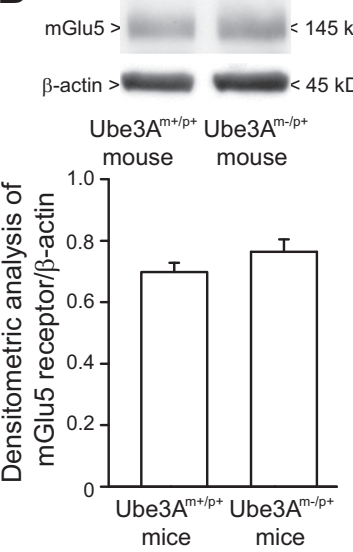

$\mathbf{E}$
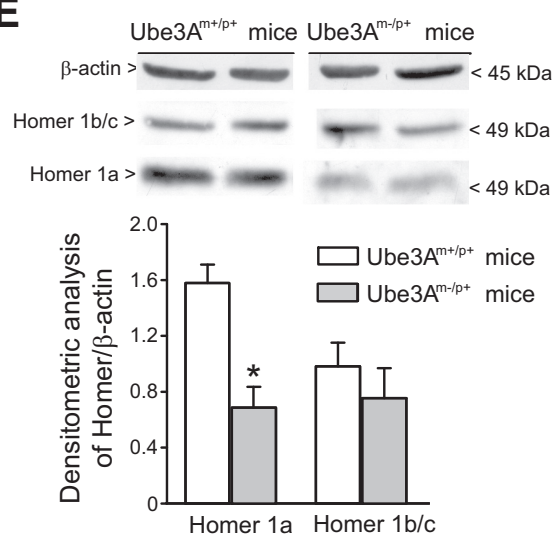

G

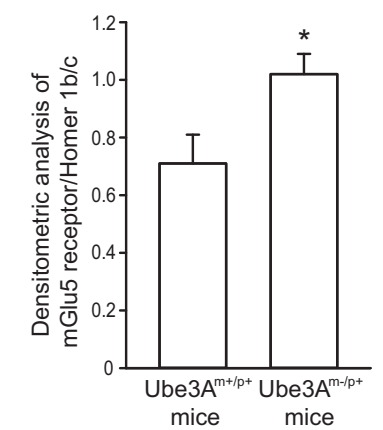

Figure 5. Changes in mGlu5 receptor coupling to Homer proteins in the hippocampus of Ube $3 \mathrm{~A}^{\mathrm{m}-/ \mathrm{p}+}$ mice. $\boldsymbol{A}, \boldsymbol{B}, \mathrm{mGlu} 5$ receptor mRNA and protein levels in the hippocampus of wild-type $(\boldsymbol{A})$ and Ube $3 \mathrm{~A}^{\mathrm{m}-\mathrm{p}+}(\boldsymbol{B})$ mice. Values are means \pm SEM of 4-8 mice per group. C, DHPG-stimulated inositol phospholipid hydrolysis in hippocampal slices. Values are means \pm SEM and were obtained from slices obtained from five mice (here, slices were pooled and the experiment was performed in triplicate). The experiment was repeated twice with identical results. $\boldsymbol{D}$, mRNA levels of pan-Homer and Homer $1 \mathrm{a}$. $\boldsymbol{E}$, Homer $1 \mathrm{~b} / \mathrm{c}$ and Homer $1 \mathrm{a}$ protein levels. Values are means \pm SEM of four mice per group. ${ }^{*} p<0.05$ versus the respective wild-type (Ube $3 A^{\mathrm{m}+/ \mathrm{p}+}$ ) mice (Student's $t$ test; $t$ values: $\boldsymbol{D}, 4.42 ; \boldsymbol{E}, 3.915)$. $\boldsymbol{F}, \boldsymbol{G}$, Levels of $\mathrm{mGlu5}$ receptors in pan-Homer $(\boldsymbol{F})$ and Homer $1 \mathrm{~b} / \mathrm{c}(\boldsymbol{G})$ immunoprecipitates. In $\boldsymbol{F}$, values $(n=6-7)$ were calculated from two independent experiments and data are expressed as percentage of values (means \pm SEM) obtained in wild-type mice. ${ }^{*} p<0.05$ versus wild-type mice values (Student's $t$ test; $t$ values, -2.2895 ). In $\boldsymbol{G}$, values ( $n=8$ mice per group) are means \pm SEM ${ }^{*} p<0.05$ (Student's $t$ test; $t$ value, -2.64 ).

in the regulation of activity-dependent synaptic plasticity (Jiang et al., 1998; Weeber et al., 2003), but its role in mGlu receptor-dependent forms of synaptic plasticity is unexplored. Here, we have shown that mGlu5 receptor-dependent LTD was enhanced in the hippocampus of AS mice, and this was associated with alterations in mGlu5 receptor coupling with Homer proteins. mGlu5 receptordependent LTD was also enhanced by the proteasome inhibitor UBE1-41, as expected (Citri et al., 2009), and the action of UBE1-41 was occluded in AS mice. Thus, the enhancement of mGlu5 receptordependent LTD in AS mice can be ascribed to the impairment of the ubiquitin/ proteasome system. Changes in mGlu receptor-dependent LTD in the hippocampus of AS mice were specific because LTD induced by low-frequency stimulation (e.g., NMDA receptordependent LTD) was unaltered. This contrasts with the finding of a reduced NMDA receptor-dependent LTD in the visual cortex of AS mice (Yashiro et al., 2009). We highlight that DHPG-induced LTD under our experimental conditions was insensitive to NMDA receptor blockade, as expected.

LTD mediated by group I mGlu receptors at the Schaffer collateral-CA1 synapses requires dendritic protein synthesis (Waung and Huber, 2009). In FXS mice, LTD is enhanced and becomes independent of new protein synthesis because of the lack of FMRP, which normally restrains translation of LTD-related proteins (Huber et al., 2002; Hou et al., 2006; Nosyreva and Huber, 2006). In apparent contrast with these findings, the mGlu5 receptor-dependent LTD in AS mice was sensitive to the protein synthesis inhibitor anisomycin to the same extent as in control mice. Thus, although the defect of Ube3A is expected to prolong the half-life of postsynaptic proteins, mGlu receptordependent LTD in AS mice retains its sensitivity to de novo protein synthesis.

Arc, which is the product of an immediate early gene, has been directly related to mechanisms of LTD mediated by group I mGlu receptors. Rapid translation of Arc mediates mGlu1/5 receptor-dependent LTD in hippocampal neurons through a persistent increase in the rate of AMPA receptor endocytosis (Waung et al., 2008). FXS mice show increased Arc levels in dendrites, and lentiviral-mediated expression of FMRP in these mice normalizes both Arc levels and LTD in the hippocampus (Niere et al., 2012). We expected to find changes in Arc levels in the 
hippocampus of AS mice because Arc is a substrate for Ube3A (Greer et al., 2010). In contrast, Arc levels did not differ between wild-type and AS hippocampal slices under the same conditions used for the induction of LTD. However, we cannot exclude the possibility that differences in Arc levels between wild-type and AS mice are present, but anatomically restricted and too small to be revealed by immunoblot analysis.

Recent data suggest that in addition to triggering protein degradation, ubiquitination can modify protein-protein interactions and protein localization and activity (Hicke, 2001; DiAntonio and Hicke, 2004; Chen and Sun, 2009). We therefore took steps to find at which level the lack of Ube3A could affect the propagation of $\mathrm{mGlu} 5$ receptor signaling. Using specific pharmacological inhibitors, we showed that mGlu5 receptor-dependent LTD in AS mice relied on the same signaling pathways that mediate LTD in wild-type mice, i.e., the PTP, MAPK, and PI3K/ mTOR pathways (Gladding et al., 2009; Collingridge et al., 2010; Lüscher and Huber, 2010). Stimulation of at least the MAPK and PI3K pathways by DHPG was unaltered in AS mice, suggesting that changes in the activity of these pathways are not responsible for the enhanced mGlu5 receptor-dependent LTD. mGlu5 receptor expression and mGlu5 receptor-mediated PI hydrolysis were also unaltered in AS mice.

AS mice differed from wild-type mice in the coupling mechanism of mGlu 5 receptors to Homer proteins. Long, constitutive isoforms of Homer proteins (Homer 1b, 1c, 2, and 3) multimerize through their $\mathrm{C}$-terminal coiled-coil domains and target mGlula and mGlu5 receptors to the postsynaptic density through interactions with SHANK (SH3 and multiple ankyrin repeat domains protein). In addition, long isoforms of Homer link mGlu la and mGlu5 receptors to signaling molecules, such as PIKE (phosphoinositide-3 kinase enhancer), EF2K (the elongation factor 2 kinase), the inositol-1,4,5-trisphosphate receptors TRPC1 and TRPC3, N-type calcium channels, and M-type potassium channels (Brakeman et al., 1997; Tu et al., 1998, 1999; Xiao et al., 1998; Kammermeier et al., 2000; Yuan et al., 2003; Kim et al., 2006). In contrast, Homer 1a, a short and activity-inducible form of Homer lacking the coiled-coil domain, acts as a dominant negative isoform by uncoupling mGlula or mGlu5 receptors from postsynaptic effectors (Kammermeier and Worley, 2007).

Recent evidence links Homer proteins to mGlu5 receptormediated synaptic plasticity and autism. Disruption of mGlu5 interaction with Homer proteins blocks mGlu5 receptordependent LTD and protein synthesis in normal mice (Ronesi et al., 2012). In FXS mice, mGlu5 receptors are less associated with the long Homer isoforms and more associated with Homer 1a (Giuffrida et al., 2005; Ronesi et al., 2012). Genetic deletion of Homer la corrects several phenotypes in FXS mice, but not the enhancement of mGlu5 receptor-dependent LTD in the hippocampus (Ronesi et al., 2012). The gene encoding for Homer 1 has been identified as a novel risk gene for nonsyndromic autism. Rare Homer 1 gene variants that potentially affect protein function cosegregate closely with autism among children of affected families (Kelleher et al., 2012).

In AS mice, changes in the coupling of mGlu5 receptors to Homer proteins were opposite to those seen in FXS mice. AS mice showed reduced Homer 1a mRNA and protein levels, and increased association of mGlu5 receptors with Homer proteins in immunoprecipitates. The reduction of Homer 1a in AS mice was unexpected because Homer $1 \mathrm{a}$ is a substrate for ubiquitination, and proteasome inhibitors are known to enhance Homer 1a levels (Ageta et al., 2001). Perhaps the lack of
Ube3A enhances the stability of a negative regulator of Homer 1a, which may function at transcriptional or translational levels. Alternatively, in AS mice the Homer 1a phenotype may lay upstream of the proteasome system, which may help to explain why Homer la levels are not enhanced despite the lack of Ube3A. It will be interesting to examine whether an enhanced coupling of mGlu5 receptors to long Homer isoforms has any influence on the efficiency of the ubiquitine/proteasomal system. Whatever the mechanism, the reduction of Homer 1a suggests that mGlu5 receptors are more efficiently coupled to postsynaptic effectors in AS mice. This fits nicely with the enhanced mGlu5 receptor-dependent LTD found in AS mice, although the precise mechanism that is ultimately responsible for the amplification of LTD is unknown. It is intriguing that in FXS and AS mice opposite changes in mGlu5/Homer coupling are associated with an enhanced mGlu5 receptordependent LTD. One should take into account the fact that a reduced association of mGlu5 receptors to long Homer isoforms restrains receptor coupling to postsynaptic effectors on one side (Kammermeier and Worley, 2007), but enhances the agonist-independent "constitutive" activity of mGlu5 receptors on the other side (Ango et al., 2001). Whether changes in the constitutive activity of mGlu5 receptors have any role in the pathological phenotype of AS mice is unknown.

In conclusion, we have described for the first time the association of AS with abnormalities in the interaction between mGlu5 receptors and Homer proteins, and an enhancement of mGlu5 receptor-dependent LTD in the hippocampus. These findings lay the groundwork for the use of mGlu5 receptor antagonists in models of AS.

\section{References}

Ageta H, Kato A, Hatakeyama S, Nakayama K, Isojima Y, Sugiyama H (2001) Regulation of the level of Vesl-1S/Homer-1a proteins by ubiquitinproteasome proteolytic systems. J Biol Chem 276:15893-15897. CrossRef Medline

Ango F, Prézeau L, Muller T, Tu JC, Xiao B, Worley PF, Pin JP, Bockaert J, Fagni L (2001) Agonist-independent activation of metabotropic glutamate receptors by the intracellular protein Homer. Nature 411:962-965. CrossRef Medline

Auerbach BD, Osterweil EK, Bear MF (2011) Mutations causing syndromic autism define an axis of synaptic pathophysiology. Nature 480:63-68. CrossRef Medline

Bear MF, Huber KM, Warren ST (2004) The mGluR theory of fragile X mental retardation. Trends Neurosci 27:370-377. CrossRef Medline

Bhakar AL, Dölen G, Bear MF (2012) The pathophysiology of fragile X (and what it teaches us about synapses). Annu Rev Neurosci 35:417-443. CrossRef Medline

Brakeman PR, Lanahan AA, O'Brien R, Roche K, Barnes CA, Huganir RL, Worley PF (1997) Homer: a protein that selectively binds metabotropic glutamate receptors. Nature 386:284-288. CrossRef Medline

Chen ZJ, Sun LJ (2009) Nonproteolytic functions of ubiquitin in cell signaling. Mol Cell 33:275-286. CrossRef Medline

Citri A, Soler-Llavina G, Bhattacharyya S, Malenka RC (2009) N-methyl-Daspartate receptor- and metabotropic glutamate receptor-dependent long-term depression are differentially regulated by the ubiquitinproteasome system. Eur J Neurosci 30:1443-1450. CrossRef Medline

Collingridge GL, Peineau S, Howland JG, Wang YT (2010) Long-term depression in the CNS. Nat Rev Neurosci 11:459-473. CrossRef Medline

DiAntonio A, Hicke L (2004) Ubiquitin-dependent regulation of the synapse. Annu Rev Neurosci 27:223-246. CrossRef Medline

Dölen G, Osterweil E, Rao BS, Smith GB, Auerbach BD, Chattarji S, Bear MF (2007) Correction of fragile X syndrome in mice. Neuron 56:955-962. CrossRef Medline

Dong C, Upadhya SC, Ding L, Smith TK, Hegde AN (2008) Proteasome inhibition enhances the induction and impairs the maintenance of latephase long-term potentiation. Learn Mem 15:335-347. CrossRef Medline Ehlers MD (2003) Activity level controls postsynaptic composition and sig- 
naling via the ubiquitin-proteasome system. Nat Neurosci 6:231-342. CrossRef Medline

Faas GC, Adwanikar H, Gereau RW 4th, Saggau P (2002) Modulation of presynaptic calcium transients by metabotropic glutamate receptor activation: a differential role in acute depression of synaptic transmission and long-term depression. J Neurosci 22:6885-6890. Medline

Feng Y, Zhang F, Lokey LK, Chastain JL, Lakkis L, Eberhart D, Warren ST (1995) Translational suppression by trinucleotide repeat expansion at FMR1. Science 268:731-734. CrossRef Medline

Giuffrida R, Musumeci S, D’Antoni S, Bonaccorso CM, Giuffrida-Stella AM, Oostra BA, Catania MV (2005) A reduced number of metabotropic glutamate subtype 5 receptors are associated with constitutive Homer proteins in a mouse model of fragile X syndrome. J Neurosci 25:8908-89016. CrossRef Medline

Gladding CM, Fitzjohn SM, Molnár E (2009) Metabotropic glutamate receptor-mediated long-term depression: molecular mechanisms. Pharmacol Rev 61:395-412. CrossRef Medline

Greer PL, Hanayama R, Bloodgood BL, Mardinly AR, Lipton DM, Flavell SW, Kim TK, Griffith EC, Waldon Z, Maehr R, Ploegh HL, Chowdhury S, Worley PF, Steen J, Greenberg ME (2010) The Angelman syndrome protein Ube3A regulates synapse development by ubiquitinating arc. Cell 140:704-716. CrossRef Medline

Hagerman R, Lauterborn J, Au J, Berry-Kravis E (2012) Fragile X syndrome and targeted treatment trials. Results Probl Cell Differ 54:297-335. CrossRef Medline

Hicke L (2001) Protein regulation by monoubiquitin. Nat Rev Mol Cell Biol 2:195-201. CrossRef Medline

Hou L, Klann E (2004) Activation of the phosphoinositide 3-kinase-Aktmammalian target of rapamycin signaling pathway is required for metabotropic glutamate receptor-dependent long-term depression. J Neurosci 24:6352-6361. CrossRef Medline

Hou L, Antion MD, Hu D, Spencer CM, Paylor R, Klann E (2006) Dynamic translational and proteasomal regulation of fragile $\mathrm{X}$ mental retardation protein controls mGluR-dependent long-term depression. Neuron 51: 441-454. CrossRef Medline

Huber KM, Kayser MS, Bear MF (2000) Role for rapid dendritic protein synthesis in hippocampal mGluR-dependent long-term depression. Science 288:1254-1257. CrossRef Medline

Huber KM, Roder JC, Bear MF (2001) Chemical induction of mGluR5- and protein synthesis-dependent long-term depression in hippocampal area CA1. J Neurophysiol 86:321-325. Medline

Huber KM, Gallagher SM, Warren ST, Bear MF (2002) Altered synaptic plasticity in a mouse model of fragile X mental retardation. Proc Natl Acad Sci U S A 99:7746-7750. CrossRef Medline

Jiang YH, Armstrong D, Albrecht U, Atkins CM, Noebels JL, Eichele G, Sweatt JD, Beaudet AL (1998) Mutation of the Angelman ubiquitin ligase in mice causes increased cytoplasmic p53 and deficits of contextual learning and long-term potentiation. Neuron 21:799-811. CrossRef Medline

Kammermeier PJ, Worley PF (2007) Homer la uncouples metabotropic glutamate receptor 5 from postsynaptic effectors. Proc Natl Acad Sci U S A 104:6055-6060. CrossRef Medline

Kammermeier PJ, Xiao B, Tu JC, Worley PF, Ikeda SR (2000) Homer proteins regulate coupling of group I metabotropic glutamate receptors to N-type calcium and M-type potassium channels. J Neurosci 20:72387245. Medline

Kelleher RJ 3rd, Bear MF (2008) The autistic neuron: troubled translation? Cell 135:401-406. CrossRef Medline

Kelleher RJ 3rd, Geigenmüller U, Hovhannisyan H, Trautman E, Pinard R, Rathmell B, Carpenter R, Margulies D (2012) High-throughput sequencing of mGluR signaling pathway genes reveals enrichment of rare variants in autism. PLoS One 7:e35003. CrossRef Medline

Kim JY, Zeng W, Kiselyov K, Yuan JP, Dehoff MH, Mikoshiba K, Worley PF, Muallem S (2006) Homer 1 mediates store- and inositol 1,4,5trisphosphate receptor-dependent translocation and retrieval of TRPC3 to the plasma membrane. J Biol Chem 281:32540-32549. CrossRef Medline

Kishino T, Lalande M, Wagstaff J (1997) UBE3A/E6-AP mutations cause Angelman syndrome. Nat Genet 15:70-73. CrossRef Medline

Krueger DD, Bear MF (2011) Toward fulfilling the promise of molecular medicine in fragile X syndrome. Annu Rev Med 62:411-429. CrossRef Medline

Lüscher C, Huber KM (2010) Group 1 mGluR-dependent synaptic long- term depression: mechanisms and implications for circuitry and disease. Neuron 65:445-459. CrossRef Medline

Manabe T (1997) Two forms of hippocampal long-term depression, the counterpart of long-term potentiation. Rev Neurosci 8:179-193. CrossRef Medline

Michalon A, Sidorov M, Ballard TM, Ozmen L, Spooren W, Wettstein JG, Jaeschke G, Bear MF, Lindemann L (2012) Chronic pharmacological mGlu5 inhibition corrects fragile $\mathrm{X}$ in adult mice. Neuron 74:49-56. CrossRef Medline

Moult PR, Corrêa SA, Collingridge GL, Fitzjohn SM, Bashir ZI (2008) Coactivation of $\mathrm{p} 38$ mitogen-activated protein kinase and protein tyrosine phosphatase underlies metabotropic glutamate receptor-dependent long-term depression. J Physiol 586:2499-2510. CrossRef Medline

Nicoletti F, Iadarola MJ, Wroblewski JT, Costa E (1986) Excitatory amino acid recognition sites coupled with inositol phospholipid metabolism: developmental changes and interaction with $\alpha 1$-adrenoceptors. Proc Natl Acad Sci U S A 83:1931-1935. CrossRef Medline

Nicoletti F, Bockaert J, Collingridge GL, Conn PJ, Ferraguti F, Schoepp DD, Wroblewski JT, Pin JP (2011) Metabotropic glutamate receptors: from the workbench to the bedside. Neuropharmacology 60:1017-1041. CrossRef Medline

Niere F, Wilkerson JR, Huber KM (2012) Evidence for a fragile X mental retardation protein-mediated translational switch in metabotropic glutamate receptor-triggered Arc translation and long-term depression. J Neurosci 32:5924-5936. CrossRef Medline

Nisticò R, Mango D, Mandolesi G, Piccinin S, Berretta N, Pignatelli M, Feligioni M, Musella A, Gentile A, Mori F, Bernardi G, Nicoletti F, Mercuri NB, Centonze D (2013) Inflammation subverts hippocampal synaptic plasticity in experimental multiple sclerosis. PLoS One 8:e54666. CrossRef Medline

Nosyreva ED, Huber KM (2006) Metabotropic receptor-dependent longterm depression persists in the absence of protein synthesis in the mouse model of fragile X syndrome. J Neurophysiol 95:3291-3295. CrossRef Medline

Park S, Park JM, Kim S, Kim JA, Shepherd JD, Smith-Hicks CL, Chowdhury S, Kaufmann W, Kuhl D, Ryazanov AG, Huganir RL, Linden DJ, Worley PF (2008) Elongation factor 2 and fragile X mental retardation protein control the dynamic translation of Arc/Arg3.1 essential for mGluR-LTD. Neuron 59:70-83. CrossRef Medline

Ronesi JA, Huber KM (2008) Homer interactions are necessary for metabotropic glutamate receptor-induced long-term depression and translational activation. J Neurosci 28:543-547. CrossRef Medline

Ronesi JA, Collins KA, Hays SA, Tsai NP, Guo W, Birnbaum SG, Hu JH, Worley PF, Gibson JR, Huber KM (2012) Disrupted Homer scaffolds mediate abnormal mGluR5 function in a mouse model of fragile X syndrome. Nat Neurosci 15:431-440, S1. CrossRef Medline

Sato M, Stryker MP (2010) Genomic imprinting of experience-dependent cortical plasticity by the ubiquitin ligase gene Ube3a. Proc Natl Acad Sci U S A 107:5611-5616. CrossRef Medline

Steffenburg S, Gillberg CL, Steffenburg U, Kyllerman M (1996) Autism in Angelman syndrome: a population-based study. Pediatr Neurol 14:131136. CrossRef Medline

Takayasu Y, Takeuchi K, Kumari R, Bennett MV, Zukin RS, Francesconi A (2010) Caveolin-1 knockout mice exhibit impaired induction of mGluRdependent long-term depression at CA3-CA1 synapses. Proc Natl Acad Sci U S A 107:21778-21783. CrossRef Medline

Tu JC, Xiao B, Yuan JP, Lanahan AA, Leoffert K, Li M, Linden DJ, Worley PF (1998) Homer binds a novel proline-rich motif and links group 1 metabotropic glutamate receptors with IP3 receptors. Neuron 21:717726. CrossRef Medline

Tu JC, Xiao B, Naisbitt S, Yuan JP, Petralia RS, Brakeman P, Doan A, Aakalu VK, Lanahan AA, Sheng M, Worley PF (1999) Coupling of mGluR/ Homer and PSD-95 complexes by the Shank family of postsynaptic density proteins Neuron 23:583-592. CrossRef

Volk LJ, Daly CA, Huber KM (2006) Differential roles for group 1 mGluR subtypes in induction and expression of chemically induced hippocampal long-term depression. J Neurophysiol 95:2427-2438. Medline

Waung MW, Huber KM (2009) Protein translation in synaptic plasticity: mGluR-LTD, Fragile X. Curr Opin Neurobiol 19:319-326. CrossRef Medline

Waung MW, Pfeiffer BE, Nosyreva ED, Ronesi JA, Huber KM (2008) Rapid 
translation of Arc/Arg3.1 selectively mediates mGluR-dependent LTD through persistent increases in AMPAR endocytosis rate. Neuron 59:8497. CrossRef Medline

Weeber EJ, Jiang YH, Elgersma Y, Varga AW, Carrasquillo Y, Brown SE, Christian JM, Mirnikjoo B, Silva A, Beaudet AL, Sweatt JD (2003) Derangements of hippocampal calcium/calmodulin-dependent protein kinase II in a mouse model for Angelman mental retardation syndrome. J Neurosci 23:2634-2644. Medline

Williams CA (2005) Neurological aspects of the Angelman syndrome. Brain Dev 27:88-94. CrossRef Medline

Xiao B, Tu JC, Petralia RS, Yuan JP, Doan A, Breder CD, Ruggiero A, Lanahan AA, Wenthold RJ, Worley PF (1998) Homer regulates the association of group 1 metabotropic glutamate receptors with multivalent complexes of Homer-related, synaptic proteins. Neuron 21:707-716. CrossRef Medline

Yashiro K, Riday TT, Condon KH, Roberts AC, Bernardo DR, Prakash R, Weinberg RJ, Ehlers MD, Philpot BD (2009) Ube3a is required for experience-dependent maturation of the neocortex. Nat Neurosci 12: 777-783. CrossRef Medline

Yuan JP, Kiselyov K, Shin DM, Chen J, Shcheynikov N, Kang SH, Dehoff MH, Schwarz MK, Seeburg PH, Muallem S, Worley PF (2003) Homer binds TRPC family channels and is required for gating of TRPC1 by IP3 receptors. Cell 114:777-789. CrossRef Medline

Zucker RS (1989) Short-term synaptic plasticity. Annu Rev Neurosci 12:1331. CrossRef Medline 